Article

\title{
Aphis Glycines Virus 2, a Novel Insect Virus with a Unique Genome Structure
}

\author{
Sijun Liu, Diveena Vijayendran ${ }^{\dagger}$, Yuting Chen and Bryony C. Bonning * \\ Department of Entomology, Iowa State University, Ames, IA 50011, USA; sliu@iastate.edu (S.L.); \\ diveena@genetics.med.harvard.edu (D.V.); yutingc@iastate.edu (Y.C.) \\ * Correspondence: bbonning@iastate.edu; Tel.: +1-515-294-1989 \\ † Present address: Department of Genetics, Harvard Medical School, Boston, MA 02115, USA. \\ Academic Editor: Karyn Johnson \\ Received: 2 September 2016; Accepted: 8 November 2016; Published: 19 November 2016
}

\begin{abstract}
The invasive soybean aphid, Aphis glycines, is a major pest in soybeans, resulting in substantial economic loss. We analyzed the A. glycines transcriptome to identify sequences derived from viruses of $A$. glycines. We identified sequences derived from a novel virus named Aphis glycines virus 2 (ApGlV2). The assembled virus genome sequence was confirmed by reverse transcription polymerase chain reaction (RT-PCR) and Sanger sequencing, conserved domains were characterized, and distribution, and transmission examined. This virus has a positive sense, single-stranded RNA genome of $\sim 4850 \mathrm{nt}$ that encodes three proteins. The RNA-dependent RNA polymerase (RdRp) of ApGlV2 is a permuted RdRp similar to those of some tetraviruses, while the capsid protein is structurally similar to the capsid proteins of plant sobemoviruses. ApGlV2 also encodes a larger minor capsid protein, which is translated by a readthrough mechanism. ApGlV2 appears to be widespread in A. glycines populations and to persistently infect aphids with a $100 \%$ vertical transmission rate. ApGIV2 is susceptible to the antiviral RNA interference (RNAi) pathway. This virus, with its unique genome structure with both plant- and insect-virus characteristics, is of particular interest from an evolutionary standpoint.
\end{abstract}

Keywords: insect virus; soybean aphid; plant virus; readthrough domain; small RNA virus

\section{Introduction}

Aphids are major pests of agricultural crops, causing damage to plants by feeding on plant phloem and by the transmission of plant viruses [1,2]. The soybean aphid, Aphis glycines Matsumura was introduced into North America in 2000 and has since become a primary pest of soybeans [3]. The estimated losses resulting from reduced soybean yield combined with the cost of management of the soybean aphid in North America are significant [4]. Current management strategies for A. glycines populations depend primarily on the use of chemical insecticides. Breeding of soybean cultivars that encode A. glycines resistance genes (the "resistance to A. glycines" or Rag lines) show promise, but aphid biotypes resistant to those cultivars have been identified [5]. Identification of viruses that infect $A$. glycines will allow for investigation of their potential for use in management of $A$. glycines.

Multiple viruses that infect aphids causing serious pathology and disease have been identified. These include viruses with positive sense, single-stranded RNA (+ssRNA) genomes such as the dicistroviruses, e.g., Aphid lethal paralysis virus (ALPV) [6] and Rhopalosiphum padi virus (RhPV) [7]; an Iflavirus, Brevicoryne brassicae virus [8]; and unassigned small RNA viruses such as Rosy apple aphid virus (RAAV) [9] and Acyrthosiphon pisum virus (APV) [6]. DNA viruses (Densoviruses) have also been isolated from aphids [10]. Viral disease in A. glycines has not been reported, although sequences of the common aphid viruses ALPV and RhPV were found in the A. glycines transcriptome [11]. 
Next-generation sequencing (NGS) technology has been widely used for the discovery of insect viruses, and is particularly useful for the identification of viruses that replicate in hosts without disease symptoms [12,13]. Many novel insect viruses have been discovered by analyzing NGS data from various species [2]. We analyzed the A. glycines transcriptome for assembly and identification of viral genomic sequences. A novel (+) ssRNA insect virus, named Aphis glycines virus 2 (ApGIV2), was discovered. In addition to being a new aphid virus, ApGlV2 has a unique and unusual genomic structure. It is notable that ApGIV2 has a permuted RNA-dependent RNA polymerase (RdRp), similar to those of some tetraviruses and Drosophila A virus (DAV) [14-16], while the structure of the coat protein resembles that of plant viruses. We also report on the distribution, transmission, RNA degradation, and biological properties of ApGlV2.

\section{Materials and Methods}

\subsection{Aphid Rearing}

Soybean aphid, A. glycines Matsumura populations were collected from soybean fields in Iowa, Michigan, and Ohio, USA. Soybean aphids were reared on soybean plants, Glycine max (Williams 82 cultivar) at room temperature $\left(20^{\circ} \mathrm{C}\right.$ to $\left.25^{\circ} \mathrm{C}\right)$.

\subsection{ApGlV2 Genome Assembly}

The methods used for assembly of $A$. glycines transcriptome sequence data generated using Illumina sequencing (Illumina, San Diego, CA, USA) have been described [11]. Briefly, total RNA was extracted from $A$. glycines (whole aphids); one RNA sample was prepared with a single round of poly(A) purification (which depletes $50 \%-75 \%$ of RNA without poly(A) tails) and a second sample was prepared with the standard two rounds of poly(A) purification. cDNA was synthesized according to Illumina protocols. The sequencing reads were trimmed to remove adaptor sequences, and reads assembled using the Velvet assembler (European Bioinformatics Institute, Hinxton, Cambridgeshire, UK [7]. The resulting contigs were used for Basic Local Alignment Search Tool (BLAST) analysis against the National Center for Biotechnology Information (NCBI) nr database by using the Blast2GO platform [8]. Contigs with viral genes as top hits were extracted. The contigs with viral hits were then used as subject sequences and the total contigs as query sequences for local BLAST to search for potential additional homologous RNA sequences derived from viruses. The final ApGIV2 genomic sequences were generated manually by reassembling the contigs. The Trinity assembler was also tested for ApGlV2 assembly using default settings [19].

\subsection{Establishment of Single Soybean Aphid Families}

Sequence data suggested that three viruses, ALPV [20], RhPV, and ApGIV2, were present in the laboratory colony of A. glycines. In order to isolate A. glycines infected only by ApGlV2, we established single-family aphid colonies. These colonies were also used to study the vertical transmission of ApGlV2. To establish RhPV- and ALPV-free single family aphid colonies, individual adult aphids were maintained in petri dishes containing a moist Kimwipe ${ }^{\circledR}$ (Kimberly-Clark Inc., Mississauga, Ontario, Canada) and a G. max leaf. The aphids were monitored for production of progeny. The neonates were immediately isolated at birth before contact with the leaf and individually cultured on G. max leaves in petri dishes to the adult stage. The isolated aphids were then individually transferred to a G. max plant to establish single-family aphid colonies. Aphids from the F2 generation were tested for the presence of ApGIV2, RhPV and ALPV by RT-PCR using primers detailed in Table 1.

To assess whether ApGIV2 was transmitted horizontally via the plant, leaf surfaces were treated with bleach $(10 \%)$ to eliminate honeydew and aphid contamination. Bleach-treated leaves were washed with water before being used for RNA isolation and RT-PCR for detection of ApGIV2 sequences. 
Table 1. Primers used for reverse transcription PCR (RT-PCR) and rapid amplification of cDNA ends (RACE) PCR for ApGlV2, ALPV, and RhPV in A. glycines and for PCR to test for the presence of ApGlV2 sequences in the aphid genome. F denotes a forward primer while $R$ denotes a reverse primer. N/A, not applicable.

\begin{tabular}{|c|c|c|}
\hline Primer Name & Sequence $\left(5^{\prime}-3^{\prime}\right)$ & ApGIV2 Genome Position \\
\hline Tet-F & AGTGGCTGCGCATGCTCGTT & $1695-1714$ \\
\hline Tet-R & ACGCGCCTCTCCGTTGAACT & $2604-2623$ \\
\hline ApGlV2 $3^{\prime}-F$ & CAGTACAGCAATACGGCTCATT & $4284-4305$ \\
\hline ApGlV2 3'-R & AAGGGCCTTATTACTTTTCACACTCTCTC & $4474-4502$ \\
\hline ApGlV2 5'-F & GCAGGACCTTGCCTCGCTCAAA & $160-181$ \\
\hline ApGlV2-RdRp-F & AGTGGCTGCGCATGCTCGTT & 1695-2014 \\
\hline ApGlV2-RdRp-R & ACGCGCCTCTCCGTTGAACT & $2603-2623$ \\
\hline ApGlV2 R/C-F & CACGCGCGGAATCTTTGCAG & 2976-2995 \\
\hline ApGlV2 R/C-R & TCGGTCTTGGCGGCGTCATA & $3825-3845$ \\
\hline ApGlV2-CP-F & AGCAGAGCTCAACACGACGAACCAAG & $3315-3329$ \\
\hline ApGlV2-CP-R & AGCAAGCTTCTAAGCTCTCGTG & 3953-3965 \\
\hline ApGlV2 C/T-F & TGTGACTCCGACACCGTCGAA & 3885-3905 \\
\hline ApGlV2 C/T-R & GCACCGGGAGAAATCCCAGAGT & $4424-4445$ \\
\hline ApGIV2 3' RACE & TCTCCCGGTGCCTCGTCTCACCACAGG & $4435-4461$ \\
\hline ApGlV2-sgRNA 5' RACE & $\begin{array}{l}\text { CCCGAGAGTTTTATTTATGCTGGTGGACG } \\
\text { ATATGGGCAGAGACA }\end{array}$ & $3748-3791$ \\
\hline ApGlV2 5' RACE & AAGTGCCGTAGCGCTGCCTCGAGCAC & $476-501$ \\
\hline ALPV-F & TGAACTTCGTGCAACGAACACTGTT & N/A \\
\hline ALPV-R & TCCGCCTGCGTTAGGAAGAAGA & $\mathrm{N} / \mathrm{A}$ \\
\hline RhPV-F & AATCTGGCGTTGACGCGCTC & $\mathrm{N} / \mathrm{A}$ \\
\hline RhPV-R & TCССССАTCATCAACATAGATGCGT & $\mathrm{N} / \mathrm{A}$ \\
\hline qRT-PCR ApGlV2-F & TCCCCGCCACGTGAAGTGAA & $2624-2643$ \\
\hline qRT-PCR ApGIV2-R & GCTACTGCGTGCGTGGTGAA & $2822-2841$ \\
\hline
\end{tabular}

\subsection{ApGlV2 Virion Purification}

To isolate ApGIV2 virions, A. glycines infected with only ApGIV2 (1.5 to $3 \mathrm{~g}$ ) were ground in liquid nitrogen. The homogenate was re-suspended in $20 \mathrm{~mL} 0.01 \mathrm{M}$ sodium phosphate buffer $(137 \mathrm{mM}$ $\mathrm{NaCl}, 2.7 \mathrm{mM} \mathrm{KCl}, 10 \mathrm{mM} \mathrm{Na}_{2} \mathrm{HPO}_{4}, 1.8 \mathrm{mM} \mathrm{KH}_{2} \mathrm{PO}_{4}, \mathrm{pH} 7.0$ ) and centrifuged at $5000 \mathrm{rpm}$ for $5 \mathrm{~min}$ in a F21-8X50y rotor using a Sorvall RC-6f centrifuge (Thermo Scientific, Waltham, MA, USA). The supernatant was collected and diluted using 0.3 volumes of chloroform and isoamyl alcohol (24:1), followed by centrifugation at $8000 \mathrm{rpm}$ for $10 \mathrm{~min}$. Virions were precipitated overnight using $2.3 \%$ $\mathrm{NaCl}$ and $7 \%$ polyethylene glycol (PEG; $8000(w / v)$ ), followed by centrifugation at 12,000 rpm for $30 \mathrm{~min}$. Virons were resuspended in $2 \mathrm{~mL}$ TES buffer ( $10 \mathrm{mM}$ Tris-HCl, pH 7.5, $2 \mathrm{mM}$ EDTA, $150 \mathrm{mM}$ $\mathrm{NaCl}$ ), and PEG was removed by centrifugation at $13,000 \times \mathrm{g}$ for $30 \mathrm{~min}$ twice. The virus supernatant was passed through a $20 \%$ sucrose cushion by centrifugation at 55,000 rpm for $4 \mathrm{~h}$ (Beckman Coulter rotor TLA 120.2, Indianapolis IN, USA). The virion pellet was resuspended in $50 \mu \mathrm{L}$ TES buffer. All purification and centrifugation steps were conducted at $4{ }^{\circ} \mathrm{C}$.

\subsection{Characterization of ApGlV2 CP and CP-RTD Proteins}

To identify ApGlV2 coat proteins, purified ApGlV2 samples were subjected to 15\% sodium dodecyl sulfate polyacrylamide gel electrophoresis (SDS-PAGE) and the gel stained with Coomassie brilliant blue. Individual protein bands were cut from the gel and used for peptide sequencing using in-gel digestion and peptide mass fingerprinting. Digested peptides were analyzed by mass spectrometry (MS) or MS/MS at the Iowa State University Protein Facility (Ames, IA, USA). 
All MS/MS samples were analyzed using Mascot (version 2.2.0.7, Matrix Science, London, UK), and Sequest HT using Proteome Discoverer 1.4 (Thermo Scientific, Waltham, MA, USA) with the translated soybean aphid transcriptome, or ApGlV2 structural proteins as reference assuming digestion with enzyme trypsin.

\subsection{Transmission Electron Microscopy}

Purified virions $(10 \mu \mathrm{L})$, were pipetted onto a carbon film grid. The grid was negatively stained with $2 \%$ aqueous uranyl-acetate for $30 \mathrm{~s}$. The virus particles were visualized using a JEOL 2100 scanning/transmission electron microscope (JEOL USA, Inc, Peabody, MA, USA) using standard procedures.

\subsection{RNA and DNA Purification from Aphids}

Total RNA from aphids, G. max or viral RNA from ApGIV2 virions was isolated using TRIzol ${ }^{\circledR}$ reagent (Invitrogen, Carlsbad, CA, USA) following the manufacturer's instructions. Aphids $(\sim 100 \mu \mathrm{L})$ were ground in $1 \mathrm{~mL}$ of TRIzol ${ }^{\circledR}$ reagent using a pestle in a microcentrifuge tube. For isolation of viral RNA, $100 \mu \mathrm{L}$ of purified virus was mixed with $1 \mathrm{~mL}$ of TRIzol ${ }^{\circledR}$ reagent in a microcentrifuge tube, briefly vortexed and incubated at $70{ }^{\circ} \mathrm{C}$ for $10 \mathrm{~min}$. For extraction of plant RNA, 2 to $3 \mathrm{G}$. max leaves were grouped together for each sample tested. The leaves were homogenized using a mortar and pestle in liquid nitrogen. The homogenate was mixed with $1 \mathrm{~mL}$ TRIzol ${ }^{\circledR}$ reagent. The RNA purification protocol followed the manufacturer's instructions with the modification of overnight RNA precipitation in isopropanol at $-80^{\circ} \mathrm{C}$. To purify DNA from $A$. glycines, $0.1 \mathrm{~mL}$ of all stages of A. glycines were ground in $800 \mu \mathrm{L}$ of DNAzol ${ }^{\circledR}$ (Invitrogen) as previously described for RNA extraction. RNA and DNA samples were re-suspended in nuclease free water and concentrations determined using a spectrophotometer. Aphid small RNA was isolated from total RNA purified as described above. Libraries of small RNA (sRNA; 17-30 nt) were prepared and sequenced at the Iowa State University DNA Facility using the TruSeq Small RNA Library Preparation Kit (Illumina) and Illumina sequencing. The sRNAs were sequenced for 50 cycles using an Illumina GA II platform.

\subsection{PCR, RT-PCR, and RACE-PCR}

Primers used for detection of viruses and for cDNA sequencing are listed in Table 1. For detection of potential ApGIV2 sequences in aphid genomic DNA [21], total DNA from A. glycines was used for PCR with 13 primer combinations that spanned the entire length of the ApGIV2 genome. The PCR was carried out using Choice-Taq ${ }^{\mathrm{TM}}$ DNA polymerase (Denville Scientific, South Plainfield, NJ, USA) with 1 cycle of $94{ }^{\circ} \mathrm{C}$ for $3 \mathrm{~min}, 35$ cycles of $94{ }^{\circ} \mathrm{C}$ for $30 \mathrm{~s}, 55^{\circ} \mathrm{C}$ for $30 \mathrm{~s}, 72{ }^{\circ} \mathrm{C}$ for $3 \mathrm{~min}$ and 1 cycle of $72{ }^{\circ} \mathrm{C}$ for $10 \mathrm{~min}$. The PCR was repeated with a reduced annealing temperature of $50^{\circ} \mathrm{C}$ to amplify products with low melting temperature primers. RT-PCR was used for generation of viral cDNA fragments for either direct sequencing of the purified PCR fragments or for sequencing of the cloned PCR fragments. One-step RT-PCR was used for synthesis of cDNA using the One-Step RT-PCR reaction kit (Qiagen, Hilden, Germany). Viral RNA (100 ng) was added to $10 \mu \mathrm{L}$ of RT-PCR mix with gene specific primers. The RT-PCR reaction was carried out with one cycle of $50^{\circ} \mathrm{C}$ for $30 \mathrm{~min}$, one cycle of $95^{\circ} \mathrm{C}$ for $15 \mathrm{~min}$, 30 cycles of $94{ }^{\circ} \mathrm{C}$ for $30 \mathrm{~s}$, (lowest Tm for primer $-5{ }^{\circ} \mathrm{C}$ ) for $30 \mathrm{~s}, 72^{\circ} \mathrm{C}$ for $2 \mathrm{~min}$ and one cycle of $72{ }^{\circ} \mathrm{C}$ for $10 \mathrm{~min}$.

The ends of the virus genome and putative subgenomic RNA were determined using rapid amplification of cDNA ends (RACE) with the SMARTer RACE cDNA amplification kit (Clontech, Mountain View, CA, USA). As ApGlV2 lacks a $3^{\prime}$ end poly (A), the tailing reaction was carried out using poly (A) polymerase (Clontech). The $3^{\prime}$ RACE ready cDNA was generated using RNA with $500 \mathrm{ng}$ of poly (A) tail added and the $5^{\prime}$ RACE ready cDNA was generated using $3 \mu \mathrm{g}$ of A. glycines total RNA, or RNA extracted from purified virions. The Advantage 2 PCR kit (Clontech) was used for the PCR reaction. For RACE, a touchdown PCR reaction was carried out for five cycles of $94{ }^{\circ} \mathrm{C}$ for $30 \mathrm{~s}$ and 
$72{ }^{\circ} \mathrm{C}$ for $3 \mathrm{~min}$, five cycles of $94{ }^{\circ} \mathrm{C}$ for $30 \mathrm{~s}, 70{ }^{\circ} \mathrm{C}$ for $30 \mathrm{~s}$ and $72{ }^{\circ} \mathrm{C}$ for $3 \mathrm{~min}$ followed by 25 cycles of $94{ }^{\circ} \mathrm{C}$ for $30 \mathrm{~s}, 68^{\circ} \mathrm{C}$ for $30 \mathrm{~s}$, and $72{ }^{\circ} \mathrm{C}$ for $3 \mathrm{~min}$.

All PCR, RT-PCR, and RACE-PCR were performed in a MyCycle Thermal Cycler (BioRad, Hercules, CA, USA). The resulting PCR, RT-PCR, and RACE-PCR products, when necessary, were isolated and purified from $1 \%$ agarose gels using the QIAquick gel extraction kit (Qiagen). The purified DNA fragments were either sequenced directly, or ligated into pGEM-T Easy (Promega, Madison, WI, USA). The plasmids were transformed into TOP 10 competent cells. Plasmids were isolated using the Epoch ${ }^{\circledR}$ Biolabs miniprep kit according to the manufacturer's instructions and sequenced at the Iowa State University DNA Facility.

\subsection{Bioinformatics Analysis}

Local BLAST and pairwise sequence alignments of RNA sequences were performed using the BioEdit Sequence Alignment Editor (version 7.2.5) [22]. ClustalW multiple alignments and phylogenetic analyses of virus genes were performed using MEGA6.06 [23]. The homology modeling program, LOMET (Local Meta-Threading-Server) was used to predict the putative protein structure of RdRp and capsid protein (CP) with default settings [24]. A Perl script was used to map small RNA reads to the ApGlV2 genome. The script was designed to map only reads with perfectly matched bases to the ApGlV2 genome sequence. Positions and orientation in the ApGlV2 genome were recorded for each mapped read. The predicted molecular mass for viral proteins was calculated using ExPASy (expasy.org). The NCBI conserved domain search engine and ExPasy domain search program [25] were used for identification of protein domains.

The 4850-nt genome sequence for ApGlV2 has been deposited in GenBank, National Center for Biotechnology Information, with accession number KR912180.

\section{Results}

\subsection{Discovery and Confirmation of the ApGlV2 Genome Sequence}

To identify viruses of $A$. glycines, we analyzed the A. glycines transcriptome [11]. Short contigs of two known aphid dicistroviruses, ALPV and RhPV were identified [20]. In addition to these two aphid dicistroviruses, we identified contigs potentially derived from new viruses by BLASTx analysis. Four contigs of 1004, 1279, 3147, and 3280 nt had hits to the putative RdRp of either DAV (Unclassified) [6], Euprosterna elaeasa virus (EEV; Permutotetraviridae; Genus Alphapermutotetravirus) [4], or Thosea asigna virus (TAV; Permutotetraviridae; Genus Alphapermutotetravirus) $[15,26]$. The RdRp of EEV, TAV, and DAV share similar protein structures, suggesting the contigs might come from the same evolutionarily derived, unknown virus. These contigs were then used as subject sequences for BLASTn to search for additional putative genomic sequences derived from the virus. Three additional viral contigs of 450-2090 nt were identified. We also used Trinity to assemble the ApGIV2 genome, and obtained ApGlV2 sequence that differed slightly at the $5^{\prime}$ - and $3^{\prime}$-UTRs. On combining all assembly results, a genome of $4836 \mathrm{nt}$ was obtained.

To confirm the ApGlV2 genome sequence, a colony of A. glycines infected with ApGlV2 alone was established. This A. glycines colony was tested using RT-PCR with primers specific to ALPV, $\mathrm{RhPV}$, and ApGlV2 to confirm the absence of dicistroviruses and the presence of ApGlV2. ApGlV2 virions were then purified from this $A$. glycines colony and examined using transmission electron microscopy. ApGlV2 virions are icosahedral particles with an estimated diameter of $30 \mathrm{~nm}$ (Figure 1A). The putative complete ApGlV2 genome sequence was amplified using RT-PCR with primers designed to span the entire assembled genome of ApGIV2. The genome sequence was confirmed by Sanger sequencing of the amplified RT-PCR products and RACE was conducted to determine the $5^{\prime}$ and $3^{\prime}$ terminal ends of the ApGIV2 genome. The $5^{\prime}$-RACE results indicated a $5^{\prime}$ end 39 nt shorter than the assembled sequence, while the $3^{\prime}$-RACE added an additional $53 \mathrm{nt}$ at the $3^{\prime}$ end of the assembled ApGIV2 genome. However, the $3^{\prime}$ terminal 24 nt of the assembled sequence differed from the $3^{\prime}$-RACE 
sequence. The final ApGlV2 sequence (with the $3^{\prime}$ sequence determined by RACE) is $4850 \mathrm{nt}$ with $46.6 \% \mathrm{~A}+\mathrm{U}$ and $53.4 \% \mathrm{G}+\mathrm{C}$.

A)

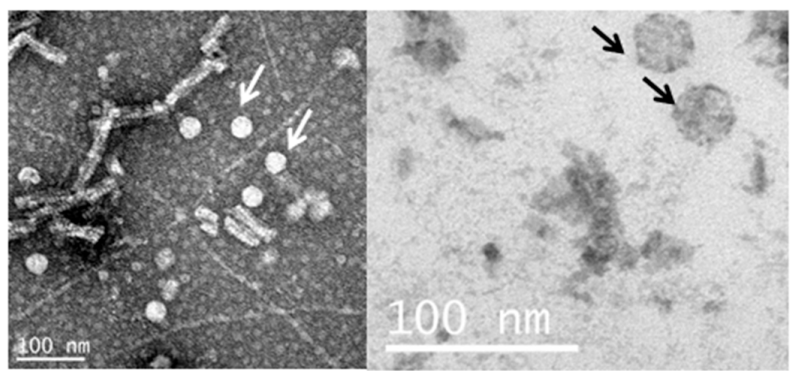

B)
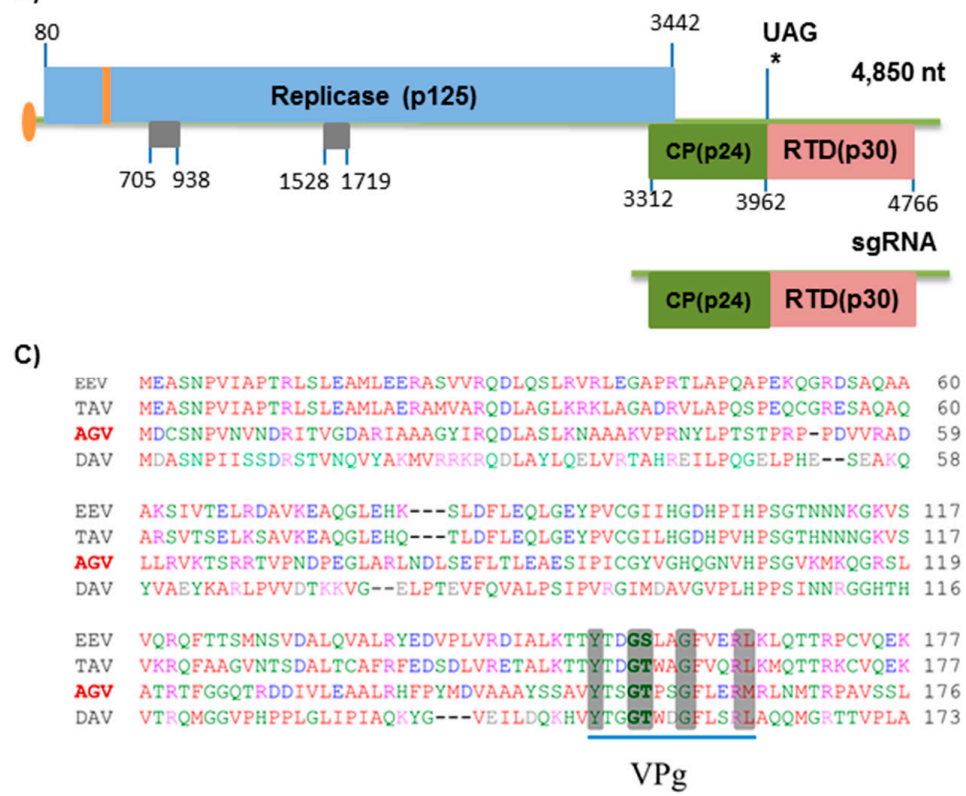

Figure 1. Aphis glycines virus 2 (ApGlV2) morphology and genomic structure. (A) Virions of ApGlV2 viewed using a transmission electron microscope. Arrows indicate ApGlV2 icosahedral virions with a diameter of $\sim 30 \mathrm{~nm}$. (B) Schematic representation of the ApGlV2 genome. The virus genome likely has a $5^{\prime}$-linked viral protein genome-linked (VPg) with the putative RNA-dependent RNA polymerase (RdRp; $125.3 \mathrm{kDa}$ ) encoded by the $5^{\prime}$ open reading frame (ORF). The putative ApGlV2 VPg is encoded at nucleotides 544 to 580 (amino acids 155-167 within the replicase ORF; shown in orange). The capsid protein $(\mathrm{CP}, 24.3 \mathrm{kDa})$ is encoded toward the $3^{\prime}$ end along with a putative readthrough domain (RTD, $30.3 \mathrm{kDa}$ ). ApGlV2 may encode a subgenomic RNA for the expression of CP and CP-RTD. An additional two potential ORFs (in gray) are located between 705-938 nt (78 aa) and 1528-1719 nt (64 aa). (C) The ApGIV2 genome has a conserved VPg domain at the $5^{\prime}$ end. Clustal W sequence alignment of $\mathrm{N}$-terminal sequences of Euprosterna elaeasa virus (EEV), Thosea asigna virus (TAV), Aphis glycines virus 2 (AGV), and Drosophila A virus (DAV). The sequence alignment shows conservation of amino acid sequences (highlighted) for the VPg at the $5^{\prime}$ end of the virus genome.

\subsection{ApGlV2 Genome Organization}

ApGlV2 has a single-stranded, positive sense RNA genome; (+)ssRNA. The viral genomic RNA has two predicted open reading frames (ORFs) (Figure 1B). ORF1 (P125) encodes a 1121-amino acid (aa) protein, containing the RdRp domain, predicted to be a replicase. The overlapping ORF2 encodes 217 aa and is predicted to encode the capsid protein (CP, P24). In addition to the two major functional ORFs, an additional 244 aa ORF3 (P30) of unknown function downstream of CP is also predicted. Although ORF3 has an in-frame AUG, it is likely that it is expressed via stop codon readthrough due to 
the polyproline linker sequence upstream of the first AUG, which is typical for the readthrough domain (RTD) of luteovirid CP-RTD [27]. The stop codon of the CP is UAG, an amber stop codon commonly found in readthrough proteins. Hence the 244 aa ORF3 could be translated by readthrough of the $\mathrm{CP}$ and form a 485 aa putative CP-RTD protein ( $55 \mathrm{kDa}$ ) (Figure 1B). The CP stop context conforms to the "Type I" classical readthrough motif, namely UAG-CAR-YYA ( $\mathrm{R}=$ purine, $\mathrm{Y}=$ pyrimidine) (cf. many plant viruses, [28], but also Providence virus, which has UAG-CAA-CUA-the same as ApGIV2). The CP and CP-RTD are likely to be translated from a subgenomic RNA based on the genomic structure, with ORF2 and ORF3 in a +1 frame relative to ORF1. This is the first insect RNA virus described that has a CP-RTD structure similar to that of plant luteovirids. In addition to the three major ORFs shown in Figure 1B, there are two potential ORFs located between 705-938 nt (78 aa) and 1528-1719 nt (64 aa). It is unknown whether these short ORFs are translated.

ApGIV2 appears to lack a poly(A) tail. The near full-length ApGIV2 genome sequence was assembled from NGS reads derived only from partially purified mRNA samples [11], and ApGlV2 sequence was not PCR amplified when reverse transcription was carried out using an oligo d(T) primer. The same region was successfully amplified, however, when a virus-specific RT primer was used (data not shown).

Viruses with RdRp homologous to that of ApGlV2 encode viral protein genome-linked (VPg) at the N-terminus of the RdRp protein. Sequence comparison of TAV, EEV DAV, and ApGIV2 shows that the RdRp of ApGlV2 includes residues consistent with conserved VPg sequences (Figure 1C).

\subsection{Analysis of Putative Subgenomic RNA}

The genome structure of ApGlV2 suggests that CP and CP-RTD are likely translated from a subgenomic RNA (sgRNA). ApGlV2 genomic RNA was unstable. Under conditions in which we could purify intact Aphid lethal paralysis virus RNA (10 kb), ApGlV2 RNA was degraded (Supplementary Materials Figure S1). Hence it was not possible to detect sgRNA by conventional methods. To detect the potential sgRNA, a primer that anneals close to the CP start codon (ApGlV2-sgRNA $5^{\prime}$ RACE, Table 1) was used for $5^{\prime}$-RACE to amplify the $5^{\prime}$-UTR of the sgRNA. The $5^{\prime}$-RACE resulted in various lengths of the $5^{\prime}$-UTR of the putative sgRNA, which were $23,64,78$, and $111 \mathrm{nt}$ upstream of the CP start codon.

\subsection{ApGlV2 Encodes a Permuted RdRp}

BLAST analysis of ApGlV2 RdRp resulted in hits to TAV, EEV, and DAV, suggesting that ApGlV2 may be a new insect virus with a non-canonical permuted RdRp Sequence comparison between ApGlV2 RdRp and the permuted RdRps of TAV, EEV, and DAV showed that the ApGlV2 RdRp has a non-canonical C-A-B-D arrangement (Figure 2A). Residues of the motifs are conserved among the RdRps of ssRNA insect viruses with permuted RdRps. However, the ApGlV2 motifs are more divergent than those of the other three insect virus permuted RdRps.

Phylogenetic analysis of the permuted RdRps of insect viruses, birnaviruses, and a plant virus shows three distinct lineages (Figure 2B) with ApGIV2, DAV, and the tetraviruses closely related to the birnaviruses, suggesting that the permuted RdRps of these viruses evolved from a common ancestor (Figure 2B). In contrast, the RdRps of the negeviruses are more closely related to a plant virus, Grapevine fleck virus (GFV). Detailed analysis of the ApGlV2 RdRp showed that although the full-length RdRp showed homology, only the N-terminal half of the ApGlV2 RdRp has significant amino acid similarity to that of EEV, TAV and DAV (query coverage $56 \%-59 \%$ with $32 \%-33 \%$ amino acid sequence identities), i.e., the sequence homology of the viral RdRp is not high at the amino acid level. To determine whether the four RdRps form similar tertiary structures, protein folding of the RdRps was predicted by homology modeling using the LOMETS server. The structure prediction results demonstrate that the RdRp of ApGlV2 has a similar tertiary structure to those of the tetraviruses and DAV (Figure 2C), despite the low sequence similarity among the permuted RdRps of these viruses. 


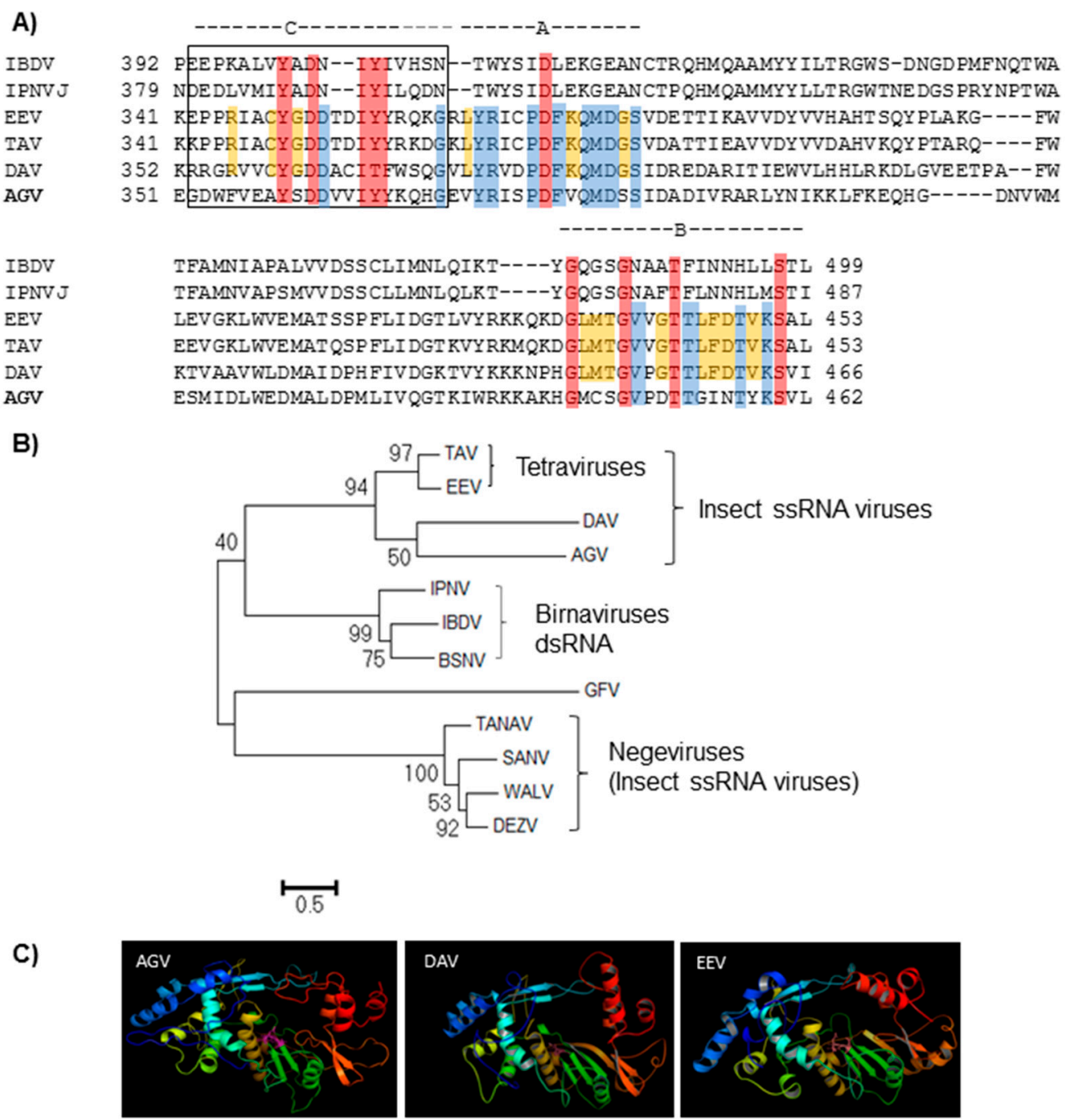

Figure 2. ApGlV2 has a non-canonical (C-A-B) RdRp, similar to those of some other insect viruses. (A) The conservation of the amino acid residues between ApGIV2, the tetraviruses; Thosea asigna virus (TAV) and Euprosterna elaeasa virus (EEV); Drosophila A virus (DAV) and birnaviruses; Infectious pancreatic necrosis virus (IPNV) and Infectious bursal disease virus (IBDV) are highlighted. Yellow highlights show conservation between EEV, TAV, and DAV but not ApGIV2 while blue highlights show conservation of EEV, TAV, and DAV with ApGIV2. Red highlights show conservation of residues between all viruses. All highlighted amino acids are key RdRp motifs. (B) Phylogenetic tree of ApGlV2 RdRp with closely related viruses and other viruses with permuted RdRp based on BLAST results of amino acid identity. Phylogenetic trees were constructed using MEGA 6.06 with the maximum likelihood method. Thosea asigna virus (TAV, accession AAQ14329.1) and EEV (AF461742_1) are closely related to but phylogenetically distinct from DAV (YP003038595.1) and ApGIV2 (AGV). The RdRps of these insect viruses are clustered with Birnaviruses, e.g., Infectious pancreatic necrosis virus (IPNV; AAV48847.1), Infectious bursal disease virus (IBDV; ACS44343.1), and Blotched snakehead virus (BSNV; YP052864). In contrast, the RdRps of negeviruses with permuted RdRps, Dezidougou virus (DEZV, AFI24669.1), Santana virus (SANV, AFI24675.1), Wallerfield virus (WALV, AIS40860.1), and Tanay virus (TANNV, YP_009028558.1) are close to a plant virus, Grapevine fleck virus (GFV, CAC84400.1), forming a distinct branch and indicating that the RdRps of negeviruses are distinct from that of ApGIV2; (C) The predicted RdRp structures for ApGIV2 (AGV), DAV, and EEV are similar. Homology modeling of tertiary protein structures of RdRp from ApGlV2, Drosophila A virus (DAV), and Euprosterna elaeasa virus (EEV). Images were generated using the LOMETS server. 


\subsection{Analysis of ApGlV2 CP and Putative RTD}

The 217 aa ApGlV2 P24 gene is a predicted capsid protein. Remarkably, there were no significant BLAST hits of the $\mathrm{CP}$ amino acid sequence to any insect or animal virus. All hits to ApGIV2 CP were from plant viruses, with the top hit (31\% amino acid identity and $79 \%$ sequence coverage) from a newly identified viral sequence isolated from bat fecal material, the so-called Bat sobemovirus (BSV; NCBI Accession No: AGN73380.1 [29]). Most of the top BLAST hits were from either sobemoviruses or viruses within the Tombusviridae (data not shown), suggesting that the ApGlV2 capsid protein is evolutionarily derived from a plant virus. DAV is also an insect virus encoding a plant virus-like $\mathrm{CP}$, and also encodes an RdRp similar to that of ApGlV2 [6]. However, the sequence identity between the CP of ApGlV2 and DAV is only $25 \%$, with sequence coverage of $46 \%$. Homology modeling to determine the tertiary structure of ApGlV2 CP suggests that ApGlV2 CP folds similar to the CP of tobacco necrosis virus (TNV; Tombusviridae Figure 3A). The sequence similarity and homology modeling results indicate that ApGlV2 is structurally similar to certain plant viruses (Sobemoviruses and Tombusviridae).

A remarkable feature of ApGIV2 is the apparent production of a CP-RTD protein by translational readthrough of the $\mathrm{CP}$ stop codon. The 267 aa RTD has a polyproline track at its N-terminus, which may function as a hinge to expose RTD on the virion surface. This type of CP-RTD was previously observed in luteovirids. The luteovirid RTD plays an important role in virus transmission by the aphid vector $[30,31]$ and also functions in virus movement and luteovirid tissue specificity (phloem restriction) in the plant $[27,32]$.

To detect the predicted CP and CP-RTD proteins, ApGIV2 particles were purified in a sucrose cushion, denatured and separated by sodium dodecyl sulfate polyacrylamide gel electrophoresis (SDS-PAGE). Seven protein bands on the gel (Figure 3B) were isolated for peptide sequencing to establish whether the seven protein bands were derived from ApGlV2. Peptide sequences from bands 4-7 matched the ApGlV2 CP sequence, indicating that these four proteins were derived from ApGIV2 CP (Supplementary Materials Figure S2). Sequences obtained from proteins with higher molecular mass (proteins 1-3) showed no similarity to virus sequences on BLAST analysis: Peptide sequences from protein band 3 were derived from Buchnera aphidicola $60 \mathrm{kDa}$ chaperonin, while sequences from protein bands 1 and 2 had no significant hits. Peptide sequences obtained for band $4(\sim 55 \mathrm{kDa})$ were derived from CP, indicating that band 4 was CP-RTD (predicted Mr $55.5 \mathrm{kDa}$ ), while band 6 of $\sim 24 \mathrm{kDa}$ was derived from CP. Unfortunately, no peptides derived from the RTD domain were detected. Protein band 5 was larger than CP but smaller than the predicted CP-RTD and band 7 was smaller than the predicted $\mathrm{CP}$, suggesting these two proteins were truncated forms of CP-RTD and CP. These peptide sequencing results combined with the molecular mass of virus proteins containing CP-derived amino acid sequences are consistent with the predictions that ApGIV2 encodes CP and CP-RTD.

Comparison of the RTD protein sequence with the sequences of other proteins did not result in any significant hits on BLASTp analysis. In addition, no conserved protein domains, family, functional sites, or motifs were identified. 
A)

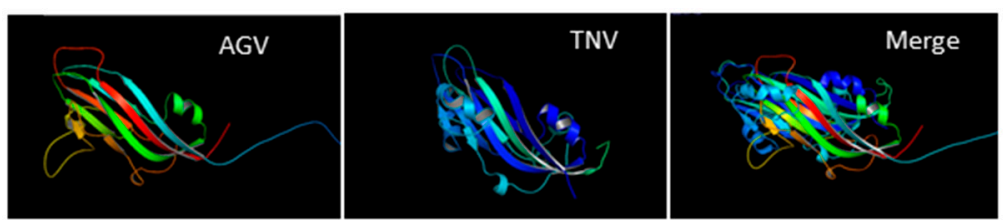

B)

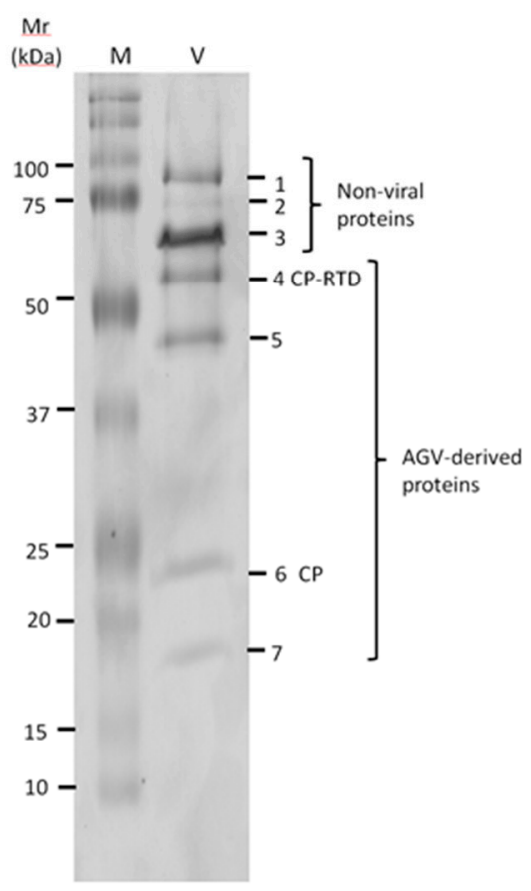

Figure 3. ApGlV2 capsid proteins. (A) The predicted structures of ApGlV2 (AGV) and tobacco necrosis virus (TNV) capsid proteins are similar. Homology modeling of tertiary protein structures of viral capsid protein for ApGlV2 and TNV (PBD:1C8N). Merge shows superimposed images of the two predicted $\mathrm{CP}$ structures with signature jelly-roll-like symmetric antiparallel $\beta$ sheets. The images were generated using the LOMETS server. (B) Identification of ApGIV2 structural proteins. Purified virions $(\mathrm{V} ; \sim 5 \mu \mathrm{g})$ were subjected to sodium dodecyl sulfate polyacrylamide gel electrophoresis (SDS-PAGE) (15\% gel) and bands cut from the Coomassie brilliant blue-stained gel. The seven bands (1-7) were isolated for peptide sequencing. M, molecular mass markers.

\subsection{Distribution and Transmission of ApGlV2}

ApGIV2 was originally isolated from a laboratory colony of $A$. glycines that had been established with aphids collected from the field in Iowa, USA. The presence of ApGIV2 in field populations of A. glycines from Michigan and Ohio, USA was confirmed by RT-PCR amplification of the RdRp region (929 bp product) of ApGlV2 (Supplementary Materials Figure S3).

To determine the mode of transmission of ApGIV2 among individual aphids, we first assessed the prevalence of ApGIV2 within the Iowa-derived laboratory A. glycines population by RT-PCR. Ten aphids were randomly isolated and used for RNA isolation. All 10 aphids were positive for ApGIV2. We then assessed the vertical transmission of ApGIV2. Sixty-three individual aphids isolated from 15 adults were tested by RT-PCR for the presence of ApGIV2. All aphids tested positive, suggesting that the virus was $100 \%$ vertically transmitted from adults to the newborn nymphs. These results suggested that all individual aphids were infected by ApGIV2. Because all tested aphids were ApGlV2-positive, whether ApGlV2 could also infect aphids by horizontal transmission could not be addressed. It is possible that ApGlV2 can be transmitted via the host plant, similar to other aphid viruses: RhPV, RAAV, Dendrolimus punctatus DNV, and Myzus persicae DNV [33,34]. RT-PCR on RNA isolated from 
the G. max leaves that were infested with aphids was conducted to test whether ApGIV2 is transmitted via the plant. No ApGlV2 RNA was detected by RT-PCR from these leaves, indicating that ApGlV2 was not introduced into the host plants (data not shown).

\subsection{ApGlV2 Is Not Detected in the Genome of A. glycines}

Insertion of sequences of persistent insect RNA viruses into the host genome has been reported for Flock house virus (FHV, Nodaviridae) and Israeli acute paralysis virus of bees (IAPV, Dicistroviridae) [21,35]. Detection of ApGIV2 in all A. glycines samples from multiple locations and the $100 \%$ vertical transmission rate prompted testing for the presence of ApGlV2 sequences in the genome of A. glycines. To eliminate the possibility that ApGIV2 genomic RNA was inserted into the A. glycines genome, we designed combinations of primer pairs spanning the entire genome of the virus and the primers were used in PCR with total DNA isolated from A. glycines. None of the sequenced PCR products were derived from the ApGIV2 genome sequence (Supplementary Materials Figure S4). We then mapped NGS DNA reads (100 bp) derived from the same Iowa soybean aphid population from which ApGlV2 was isolated [36] to the ApGlV2 genome. No genomic DNA reads mapped to ApGlV2 genomic RNA. The PCR and genomic mapping results indicate that ApGIV2 sequences were not present in the genome of $A$. glycines.

\subsection{ApGlV2 Is Targeted by the RNAi Pathway}

The RNA interference (RNAi) pathway plays a critical role in antiviral immune defense for many insect viruses 37]. To determine whether degradation of ApGIV2 is regulated by the RNAi pathway, we sequenced the sRNA of the Iowa A. glycines colony infected by ApGlV2 and an ALPV-like virus using the Illumina platform. The sRNA reads (16-30 nt) were mapped to the ApGlV2 genome to detect sRNA derived from ApGIV2. Around $0.4 \%$ of the reads (from a total of 20.6 million reads) mapped to ApGlV2 genomic RNA. A typical viral small RNA (vsRNA) distribution pattern with a peak at $22 \mathrm{nt}$ derived from both strands of the dsRNA replication intermediate was observed (Figure 4).

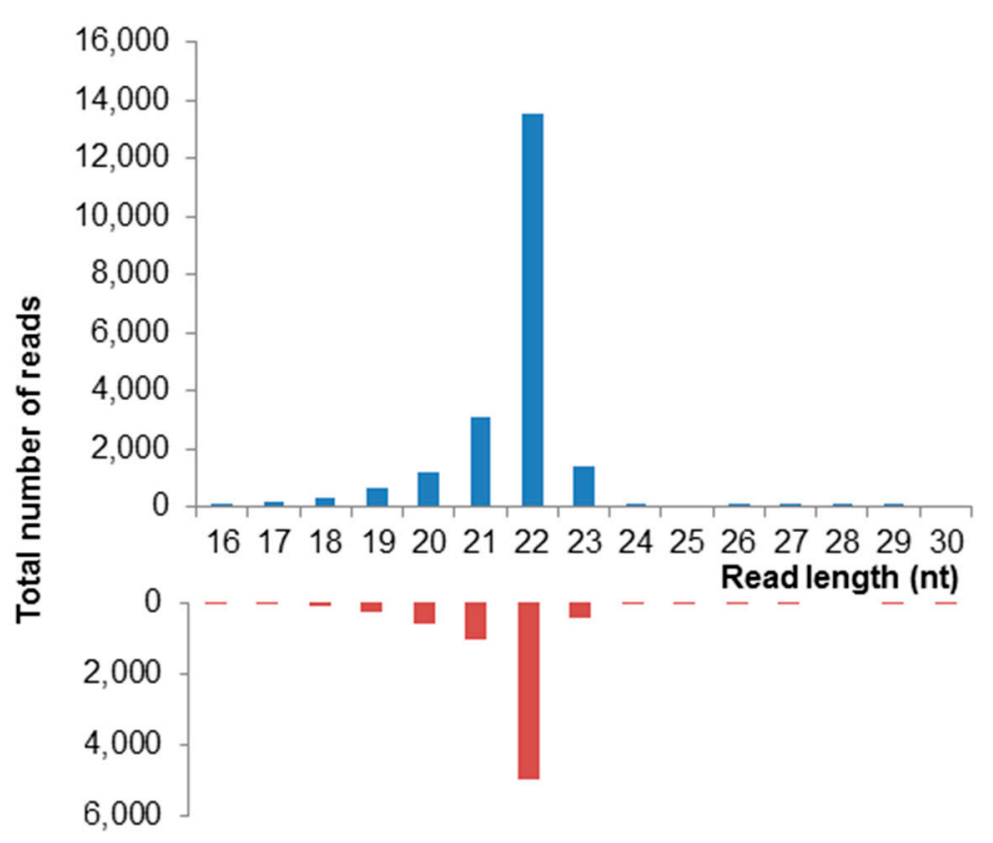

Figure 4. Virus-derived small interfering RNA (vsRNA) sequences derived from the sense (blue) and anti-sense (red) genome of ApGlV2. Reads were extracted from a small RNA sequencing dataset of A. glycines (Iowa) infected with ApGlV2 and an ALPV-like virus. The majority of the ApGlV2 vsRNAs are $22 \mathrm{nt}$, characteristic of double-stranded RNA processing by Dicer2. 


\section{Discussion}

The novel insect virus, Aphis glycines virus 2 (ApGlV2), has a unique genome structure that encodes an RdRp similar to that of insect viruses and a capsid protein resembling those of luteovirids. ApGlV2 infected all individuals in all soybean aphid populations examined and is vertically transmitted. ApGlV2 replication in A. glycines was confirmed by sRNA sequencing with virus-derived sRNA identified from both RNA strands, indicative of RNAi-mediated degradation of the viral dsRNA produced during replication. The impact of ApGIV2 infection on the soybean aphid could not be assessed due to the lack of an ApGlV2-free soybean aphid colony.

Viral RdRps are the most conserved viral proteins and share several conserved motifs in a specific order [38-40]. The arrangement of the conserved structures has a "right hand-like" shape with three conserved sub-domains, named the finger, palm, and thumb [41,42]. The palm domain consists of four of eight conserved motifs that have a canonical order described as A-B-C-D and found in most viral RdRp [39]. However, a non-canonical organization of the RdRp motifs was observed in seven ssRNA insect viruses: The tetraviruses TAV, EEV, and the unclassified virus DAV [14-16]; negeviruses isolated from mosquitoes; DEZV, SANV [43], WALV [44], and Tanay virus, TANAV [45]; three dsRNA viruses (BSNV, IPNV, and IBDV) and a plant alpha-like virus (Grapevine fleck virus, GFV) [15,16,46,47]. More recently, the sequences of five new insect viruses with permuted RdRp have been submitted to NCBI, specifically Newfield virus (NfV) (partial sequence: KP714979.1) [48], Niehaus virus (NhV) (partial sequence; KX580892), Egaro virus (EgV) (NC_030845) Daeseongdong virus (DaV2) (NC_028489) [49], and Defiwi virus (DfwV) (partial sequence; KX580893). The motif C of the RdRp in these viruses is permuted upstream of the motif A to form a non-canonical C-A-B-D arrangement.

ApGIV2 represents a new type of insect virus that also has a permuted RdRp. A permuted RdRp was first found in the insect tetraviruses (EEV and TAV), with the RdRp closely related to those of birnaviruses [15]. On the basis of this, the tetraviruses were reclassified into a new family (Permutotetraviridae) and a new genus (Alphapermutotetravirus) [14,26]. A permuted RdRp was subsequently found in DAV and Drosophila melanogaster tetravirus SW-2009a (DTRV) [50], which is actually an isolate of DAV [16]. The permuted RdRps of Negevirus, which are homologous to RdRp-2 [45], differ from those of TEV, EAV, DAV, and ApGlV2. Sequence analysis indicated that Negevirus RdRps are closely related to those of a plant virus (Citrus leprosis virus C; CiLV-C) and other plant viruses whose RdRps contain RDR-2 domains (e.g., Hibiscus green spot virus, an unclassified ssRNA virus of Higrevirus and Grapevine fleck virus) [43,45].

In addition to negeviruses, and permutotetraviruses, the recent discovery of novel insect viruses suggests that permuted RdRps have evolved in divergent insect viruses. Sequence comparison suggests that the RdRp of DAV, ApGlV2 and other unassigned viruses [16,48,49] (Liu unpublished results) show some similarities to permutotetraviruses, but not to negeviruses. However, the $\mathrm{CP}$ of these viruses are diverse (data not shown).

If the CP and CP-RTD structural protein sequences of ApGIV2 are encoded by the genomic RNA (rather than the sgRNA), the $5^{\prime}$ RACE from the CP start codon region would be expected to have gone further than $111 \mathrm{nt}$. The detection of differing lengths of $5^{\prime}$ UTR is not uncommon for $5^{\prime} \mathrm{RACE}$ reactions. It is also unlikely that the reverse transcriptase fell off the RNA template during RACE due to secondary structures in the RNA as the entire genomic sequence was confirmed by RT-PCR. Although our results support the hypothesis that the structural proteins of ApGIV2 are encoded by an sgRNA, this remains to be confirmed.

The organization of the structural proteins of ApGIV2 resembles that of luteovirids. Luteovirids are exclusively transmitted by aphids in a persistent and circulative manner but do not replicate in aphids. Low sequence identity of ApGlV2 CP to those of sobemoviruses and other plant viruses suggests that these viruses only share similar virion structures. In addition, except for the polyproline sequences at the N-terminus, the ApGIV2 RTD has no sequence homology to the RTD of luteovirids, an indication that the function for ApGIV2 RTD may differ from that of luteovirids. 
Viruses encoding a CP-RTD as a large minor virus coat protein have been found in several RNA virus groups such as luteovirids, benyviruses, and alloleviviruses [51-54]. One common feature of the CP-RTD is that they all have proline-rich regions at the N-terminus of the RTD. These regions act as relatively rigid spacers to separate the RTD from the CP. In the plant viruses (luteovirids and benyviruses), the RTD is involved in virus transmission by a vector. For instance, the RTD of luteovirids facilitates (but is not essential for) virus entry and circulation in the aphid vector by interaction with the aphid gut and salivary glands [55]. For Beet necrotic yellow vein virus (BNYVV), the type member of benyviruses, the RNA2 encodes a p54 RTD containing a KTER motif that is essential for transmission of the virus by its vector Polymyxa betae (reviewed by [56]. Like other viral CP-RTD, the RTD of ApGIV2 is likely exposed on the virion surface.

Interestingly, an aphid glycoside hydrolase, a predicted lactase-phlorizin hydrolase-like protein (LPH; [57], co-purified with ApGlV2 when methods frequently used in isolation of ALPV from the pea aphid A. pisum [20] was used for isolation of ApGlV2 (data not shown). No LPH accumulation was observed in preparation of ALPV from A. pisum, suggesting that the buffer system used for purification did not result in precipitation of LPH. The biological relevance of this association of ApGIV2 with LPH if any is unclear. Because all A. glycines tested were infected with ApGlV2, it was not possible to establish an ApGIV2-free colony to verify whether a mock preparation resulted in LPH precipitation.

While the A. pisum genome encodes all major components of the RNAi pathway [58], the role of RNAi in antiviral defense in aphids has not previously been demonstrated. The detection of ApGIV2-derived vsRNA also confirms that ApGIV2 actively replicates in A. glycines with a genome that is susceptible to the host antiviral immune response. The sRNA were sequenced from a colony known to be infected by both ApGlV2 and an ALPV-like virus [20]. Dicistrovirus RNAi suppressor proteins are known to inhibit the RNAi pathway. For example, the Drosophila $C$ virus (DCV) encodes DCV-1A that binds to and inhibits the processing of dsRNA by Dicer (Dcr2) while Cricket paralysis virus (CrPV) codes for CrPV-1A which binds to Argonaute (Ago2) in RISC to inhibit the cleavage of the target RNA $[59,60]$. It is not known whether the presence of ALPV in the Iowa colony had any impact on RNAi-mediated degradation of ApGlV2, or whether ApGlV2 also encodes a suppressor of silencing.

ApGIV2 RNA extracted from purified ApGlV2 virions ran on gels as a smear, while a distinct RNA band was observed for ALPV RNA (Supplementary Materials Figure S1). A similar observation was reported for DAV with DAV RNA degraded rapidly during extraction and electrophoresis [16]. RNA extracted from some tetraviruses is unstable outside of the virion [61].

The current version of the ApGIV2 genome sequence is based on confirmation of the assembled ApGIV2 sequences by RACE. Although the $3^{\prime}$-UTR of ApGIV2 is likely correct, the $5^{\prime}$-end sequence remains uncertain. The assembled ApGlV2 sequence contained an additional $39 \mathrm{nt}$ at the $5^{\prime}$-end. Although repeated $5^{\prime}$-RACE experiments did not confirm this $39 \mathrm{nt}$, assembly of ApGIV2 from various sequencing sources showed the $39 \mathrm{nt}$ in the $5^{\prime}$-UTR (data no shown). In addition, $5^{\prime}$-RACE of sgRNA showed variable results, suggesting $5^{\prime}$-RACE is not reliable for confirming the $5^{\prime}$-end sequences of ApGIV2. Similar 5'-RACE resulting in shorter $5^{\prime}$-UTR sequences than those of the assembled viral genomes have been reported previously $[20,62,63]$, demonstrating challenges for use of this method for determining viral 5'-UTR sequences [64]. The failure of 5'-RACE could result from RNA secondary structures [63] or because of genome protection by VPg. The rapid degradation of ApGlV2 genomic RNA (Supplementary Materials Figure S1) may also contribute to a lack of 5'-RACE efficiency.

In conclusion, ApGIV2 represents a new virus type with a unique genomic structure, which encodes a permuted RdRp similar to several insect viruses, and structural proteins similar to plant viruses. ApGIV2 RNA is subject to degradation by the RNAi pathway. This study highlights the potential for the use of next-generation sequence data for identification of virus-derived sequences [13] and some of the challenges associated with confirmation of sequences identified in silico $[64,65]$. 
Supplementary Materials: The following are available online at www.mdpi.com/1999-4915/8/11/315/s1, Figure S1: Gel electrophoresis (1\% native agarose) of $2 \mu \mathrm{g}$ RNA extracted from purified ApGIV2 and ALPV-AP virions. While the ALPV-AP RNA runs at the expected size of $\sim 10 \mathrm{~kb}$, the ApGlV2 RNA runs as a smear indicative of RNA degradation. Samples visualized with ethidium bromide staining; Figure S2: Peptide sequences derived from ApGIV2 structural proteins. Peptide numbers correspond to protein bands in Figure 3B; Colors represent sequences of individual peptide fragments. Proteins were identified from these peptide sequences with high confidence based on Mascot search A2 values; Figure S3: Detection of ApGIV2 RdRp sequence from field collected A. glycines. The 929 bp RT-PCR product was detected in field collected A. glycines from Iowa, Ohio and Michigan, USA. The positive control and A. glycines samples amplified the expected PCR products. No amplification was detected in the no template control sample (NTC); Figure S4: ApGIV2 sequences were not detected in the A. glycines genome. Primers spanning the entire ApGlV2 genome were used to test for the presence of ApGIV2 sequence in the A. glycines genome. A representative agarose gel with amplified PCR products is shown. Labels indicate region of ApGIV2 genome spanned by the PCR primers. CP, capsid protein; RTD, read through domain; RdRp, RNA-dependent RNA polymerase. The sequenced PCR product from A and B did not have any significant matches to ApGIV2 or the NCBI database. PCR product C hit a pea aphid prestin-like transcript variant 5.

Acknowledgments: The authors thank Andy Michel, Doug Landis, and Matt O'Neal for provision of soybean aphids from Ohio, Michigan, and Iowa, respectively; Brad Coates, USDA, ARS for sharing the Aphis glycines genomic DNA sequence data; and Wyatt Allen Miller for helpful comments on the manuscript. Funding for this work was provided by the Iowa Soybean Association, the North Central Soybean Research Program, the Iowa State University Plant Sciences Institute Virus-Insect Interactions Initiative, and by Hatch Act and State of Iowa funds.

Author Contributions: S.L. and B.C.B. conceived the study; S.L. conducted bioinformatics analyses; D.V. and Y.C. designed and performed the experiments; S.L. and B.C.B. wrote the manuscript.

Conflicts of Interest: The authors declare no conflict of interest.

\section{References}

1. Will, T.; Vilcinskas, A. Aphid-proof plants: Biotechnology-based approaches for aphid control. Adv. Biochem. Eng. Biotechnol. 2013, 136, 179-203. [PubMed]

2. Nault, L.R. Arthropod transmission of plant viruses: A new synthesis. Annu. Entomol. Soc. Am. 1997, 90, 521-541. [CrossRef]

3. Ragsdale, D.W.; Landis, D.A.; Brodeur, J.; Heimpel, G.E.; Desneux, N. Ecology and management of the soybean aphid in North America. Annu. Rev. Entomol. 2011, 56, 375-399. [CrossRef] [PubMed]

4. Kim, C.S.; Schaible, G.; Lynn, G.; Lubowski, R.; Lee, D. Economic impacts of the U.S. soybean aphid infestation: A multi-regional competitive dynamic analysis. Agric. Resour. Econ. Rev. 2008, 37, 227-242. [CrossRef]

5. Michel, A.P.; Mittapalli, O.; Mian, R.M.A. Evolution of Soybean Aphid Biotypes: Understanding and Managing Virulence to Host-Plant Resistance; InTech: West Palm Beach, FL, USA, 2011; pp. 355-372.

6. Van den Heuvel, J.F.; Hummelen, H.; Verbeek, M.; Dullemans, A.M.; van der Wilk, F. Characteristics of Acyrthosipon pisum virus, a newly identified virus infecting the pea aphid. J. Invertebr. Pathol. 1997, 70, 169-176. [CrossRef] [PubMed]

7. D'Arcy, C.J.; Burnett, P.A.; Hewings, A.D. Detection, biological effects, and transmission of a virus of the aphid Rhopalosiphum padi. Virology 1981, 114, 268-272. [CrossRef]

8. Ryabov, E.V. A novel virus isolated from the aphid Brevicoryne brassicae with similarity to Hymenoptera picorna-like viruses. J. Gen. Virol. 2007, 88, 2590-2595. [CrossRef] [PubMed]

9. Ryabov, E.V.; Keane, G.; Naish, N.; Evered, C.; Winstanley, D. Densovirus induces winged morphs in asexual clones of the rosy apple aphid, Dysaphis plantaginea. Proc. Natl. Acad. Sci. USA 2009, 106, 8465-8470. [CrossRef] [PubMed]

10. Van Munster, M.; Dullemans, A.M.; Verbeek, M.; van den Heuvel, J.F.; Reinbold, C.; Brault, V.; Clerivet, A.; van der Wilk, F. A new virus infecting Myzus persicae has a genome organization similar to the species of the genus Densovirus. J. Gen. Virol. 2003, 84, 165-172. [CrossRef] [PubMed]

11. Liu, S.; Chougule, N.P.; Vijayendran, D.; Bonning, B.C. Deep sequencing of the transcriptomes of soybean aphid and associated endosymbionts. PLoS ONE 2012, 7, e45161. [CrossRef] [PubMed]

12. Liu, S.; Vijayendran, D.; Bonning, B.C. Next generation sequencing technologies for insect virus discovery. Viruses 2011, 3, 1849-1869. [CrossRef] [PubMed]

13. Liu, S.; Chen, Y.; Bonning, B.C. RNA virus discovery in insects. Curr. Opin. Insect Sci. 2015, 8, 54-61. [CrossRef] 
14. Zeddam, J.L.; Gordon, K.H.; Lauber, C.; Alves, C.A.; Luke, B.T.; Hanzlik, T.N.; Ward, V.K.; Gorbalenya, A.E. Euprosterna elaeasa virus genome sequence and evolution of the Tetraviridae family: Emergence of bipartite genomes and conservation of the VPg signal with the dsRNA Birnaviridae family. Virology 2010, 397, 145-154. [CrossRef] [PubMed]

15. Gorbalenya, A.E.; Pringle, F.M.; Zeddam, J.L.; Luke, B.T.; Cameron, C.E.; Kalmakoff, J.; Hanzlik, T.N.; Gordon, K.H.; Ward, V.K. The palm subdomain-based active site is internally permuted in viral RNA-dependent RNA polymerases of an ancient lineage. J. Mol. Biol. 2002, 324, 47-62. [CrossRef]

16. Ambrose, R.L.; Lander, G.C.; Maaty, W.S.; Bothner, B.; Johnson, J.E.; Johnson, K.N. Drosophila A virus is an unusual RNA virus with a $\mathrm{T}=3$ icosahedral core and permuted RNA-dependent RNA polymerase. J. Gen. Virol. 2009, 90, 2191-2200. [CrossRef] [PubMed]

17. Zerbino, D.R.; Birney, E. Velvet: Algorithms for de novo short read assembly using de Bruijn graphs. Genome Res. 2008, 18, 821-829. [CrossRef] [PubMed]

18. Conesa, A.; Gotz, S.; Garcia-Gomez, J.M.; Terol, J.; Talon, M.; Robles, M. Blast2GO: A universal tool for annotation, visualization and analysis in functional genomics research. Bioinformatics 2005, 21, 3674-3676. [CrossRef] [PubMed]

19. Haas, B.J.; Papanicolaou, A.; Yassour, M.; Grabherr, M.; Blood, P.D.; Bowden, J.; Couger, M.B.; Eccles, D.; Li, B.; Lieber, M.; et al. De novo transcript sequence reconstruction from RNA-seq using the Trinity platform for reference generation and analysis. Nat. Protoc. 2013, 8, 1494-1512. [CrossRef] [PubMed]

20. Liu, S.; Vijayendran, D.; Carrillo-Tripp, J.; Miller, W.A.; Bonning, B.C. Analysis of new aphid lethal paralysis virus (ALPV) isolates suggests evolution of two ALPV species. J. Gen. Virol. 2014, 95, 2809-2819. [CrossRef] [PubMed]

21. Goic, B.; Vodovar, N.; Mondotte, J.A.; Monot, C.; Frangeul, L.; Blanc, H.; Gausson, V.; Vera-Otarola, J.; Cristofari, G.; Saleh, M.C. RNA-mediated interference and reverse transcription control the persistence of RNA viruses in the insect model Drosophila. Nat. Immunol. 2013, 14, 396-403. [CrossRef] [PubMed]

22. Hall Bioedit 7.0.5. Available online: http://www.mbio.ncsu.edu/BioEdit/Bioedit.html (accessed on 15 June 2015).

23. Tamura, K.; Stecher, G.; Peterson, D.; Filipski, A.; Kumar, S. MEGA6: Molecular evolutionary genetics analysis version 6.0. Mol. Biol. Evol. 2013, 30, 2725-2729. [CrossRef] [PubMed]

24. Wu, S.; Zhang, Y. LOMETS: A local meta-threading-server for protein structure prediction. Nucleic Acids Res. 2007, 35, 3375-3382. [CrossRef] [PubMed]

25. Expasy search domain program. Available online: http://prosite.expasy.org/ (accessed on 5 May 2015).

26. ICTV International Committee on Taxonomy of Viruses-Virus Taxonomy: 2015 Release. Available online: http:/ / www.ictvonline.org/virustaxonomy.asp (accessed on 28 August 2015).

27. Bruyère, A.; Brault, V.; Ziegler-Graff, V.; Simonis, M.T.; Van den Heuvel, J.F.; Richards, K.; Guilley, H.; Jonard, G.; Herrbach, E. Effects of mutations in the beet western yellows virus readthrough protein on its expression and packaging and on virus accumulation, symptoms, and aphid transmission. Virology 1997, 230, 323-334. [CrossRef] [PubMed]

28. Firth, A.E.; Brierley, I. Non-canonical translation in RNA viruses. J. Gen. Virol. 2012, 93, 1385-1409. [CrossRef] [PubMed]

29. Li, L.; Victoria, J.G.; Wang, C.; Jones, M.; Fellers, G.M.; Kunz, T.H.; Delwart, E. Bat guano virome: Predominance of dietary viruses from insects and plants plus novel mammalian viruses. J. Virol. 2010, 84, 6955-6965. [CrossRef] [PubMed]

30. Brault, V.; van den Heuvel, J.F.; Verbeek, M.; Ziegler-Graff, V.; Reutenauer, A.; Herrbach, E.; Garaud, J.C.; Guilley, H.; Richards, K.; Jonard, G. Aphid transmission of beet western yellows luteovirus requires the minor capsid read-through protein P74. EMBO J. 1995, 14, 650-659. [PubMed]

31. Chay, C.A.; Gunasinge, U.B.; Dinesh-Kumar, S.P.; Miller, W.A.; Gray, S.M. Aphid transmission and systemic plant infection determinants of barley yellow dwarf luteovirus-PAV are contained in the coat protein readthrough domain and 17-kDa protein, respectively. Virology 1996, 219, 57-65. [CrossRef] [PubMed]

32. Peter, K.A.; Liang, D.; Palukaitis, P.; Gray, S.M. Small deletions in the potato leafroll virus readthrough protein affect particle morphology, aphid transmission, virus movement and accumulation. J. Gen. Virol. 2008, 89, 2037-2045. [CrossRef] [PubMed]

33. Gildow, F.E.; D'Arcy, C.J. Cytopathology and experimental host range of Rhopalosiphum padi virus, a small isometric RNA virus infecting cereal grain aphids. J. Invertebr. Pathol. 1990, 55, 245-257. [CrossRef] 
34. Van Munster, M.; Janssen, A.; Clerivet, A.; van den Heuvel, J. Can plants use an entomopathogenic virus as a defense against herbivores? Oecologia 2005, 143, 396-401. [CrossRef] [PubMed]

35. Maori, E.; Tanne, E.; Sela, I. Reciprocal sequence exchange between non-retro viruses and hosts leading to the appearance of new host phenotypes. Virology 2007, 362, 342-349. [CrossRef] [PubMed]

36. Coates, B.S.; O'Neal, M.E.; Michel, A.P. Genome resequencing of the soybean aphid, Aphis glycines. (Unpublished; manuscript in preparation).

37. Vijayendran, D.; Airs, P.M.; Dolezal, K.; Bonning, B.C. Arthropod viruses and small RNAs. J. Invertebr. Pathol. 2013, 114, 186-195. [CrossRef] [PubMed]

38. Poch, O.; Sauvaget, I.; Delarue, M.; Tordo, N. Identification of four conserved motifs among the RNA-dependent polymerase encoding elements. EMBO J. 1989, 8, 3867-3874. [PubMed]

39. Koonin, E.V. The phylogeny of RNA-dependent RNA polymerases of positive-strand RNA viruses. J. Gen. Virol. 1991, 72 Pt 9, 2197-2206. [CrossRef] [PubMed]

40. Koonin, E.V.; Dolja, V.V. Evolution and taxonomy of positive-strand RNA viruses: Implications of comparative analysis of amino acid sequences. Crit. Rev. Biochem. Mol. Biol. 1993, 28, 375-430. [CrossRef] [PubMed]

41. Hansen, J.L.; Long, A.M.; Schultz, S.C. Structure of the RNA-dependent RNA polymerase of poliovirus. Structure 1997, 5, 1109-1122. [CrossRef]

42. Van Dijk, A.A.; Makeyev, E.V.; Bamford, D.H. Initiation of viral RNA-dependent RNA polymerization. J. Gen. Virol. 2004, 85, 1077-1093. [CrossRef] [PubMed]

43. Vasilakis, N.; Forrester, N.L.; Palacios, G.; Nasar, F.; Savji, N.; Rossi, S.L.; Guzman, H.; Wood, T.G.; Popov, V.; Gorchakov, R.; et al. Negevirus: A proposed new taxon of insect-specific viruses with wide geographic distribution. J. Virol. 2013, 87, 2475-2488. [CrossRef] [PubMed]

44. Auguste, A.J.; Carrington, C.V.; Forrester, N.L.; Popov, V.L.; Guzman, H.; Widen, S.G.; Wood, T.G.; Weaver, S.C.; Tesh, R.B. Characterization of a novel Negevirus and a novel Bunyavirus isolated from Culex (Culex) declarator mosquitoes in Trinidad. J. Gen. Virol. 2014, 95, 481-485. [CrossRef] [PubMed]

45. Nabeshima, T.; Inoue, S.; Okamoto, K.; Posadas-Herrera, G.; Yu, F.; Uchida, L.; Ichinose, A.; Sakaguchi, M.; Sunahara, T.; Buerano, C.C.; et al. Tanay virus, a new species of virus isolated from mosquitoes in the Philippines. J. Gen. Virol. 2014, 95, 1390-1395. [CrossRef] [PubMed]

46. Pan, J.; Vakharia, V.N.; Tao, Y.J. The structure of a birnavirus polymerase reveals a distinct active site topology. Proc. Natl. Acad. Sci. USA 2007, 104, 7385-7390. [CrossRef] [PubMed]

47. Garriga, D.; Navarro, A.; Querol-Audí, J.; Abaitua, F.; Rodríguez, J.F.; Verdaguer, N. Activation mechanism of a noncanonical RNA-dependent RNA polymerase. Proc. Natl. Acad. Sci. USA 2007, 104, 20540-20545. [CrossRef] [PubMed]

48. Webster, C.L.; Waldron, F.M.; Robertson, S.; Crowson, D.; Ferrari, G.; Quintana, J.F.; Brouqui, J.M.; Bayne, E.H.; Longdon, B.; Buck, A.H.; et al. The discovery, distribution, and evolution of viruses associated with Drosophila melanogaster. PLoS Biol. 2015, 13, e1002210. [CrossRef] [PubMed]

49. Hang, J.; Klein, T.A.; Kim, H.C.; Yang, Y.; Jima, D.D.; Richardson, J.H.; Jarman, R.G. Genome sequences of five arboviruses in field-captured mosquitoes in a unique rural environment of South Korea. Genome Announc. 2016, 4, e01644-15. [CrossRef] [PubMed]

50. Wu, Q.; Luo, Y.; Lu, R.; Lau, N.; Lai, E.C.; Li, W.X.; Ding, S.W. Virus discovery by deep sequencing and assembly of virus-derived small silencing RNAs. Proc. Natl. Acad. Sci. USA 2010, 107, 1606-1611. [CrossRef] [PubMed]

51. Mayo, M.A.; Miller, W.A. The structure and expression of luteovirus and related genomes. In Luteoviruses; Smith, H.G., Barker, H., Jones, P., Eds.; CAB International: Wallingford, UK, 1998.

52. Rush, C.M. Ecology and epidemiology of benyviruses and plasmodiophorid vectors. Annu. Rev. Phytopathol. 2003, 41, 567-592. [CrossRef] [PubMed]

53. Smith, H.G.; Barker, H. The Luteoviridae; CABI: Wallingford, UK, 1999.

54. Rumnieks, J.; Tars, K. Crystal structure of the read-through domain from bacteriophage Q $\beta$ A1 protein. Protein Sci. 2011, 20, 1707-1712. [CrossRef] [PubMed]

55. Gray, S.; Gildow, F.E. Luteovirus-aphid interactions. Annu. Rev. Phytopathol. 2003, 41, 539-566. [CrossRef] [PubMed]

56. McGrann, G.R.; Grimmer, M.K.; Mutasa-Göttgens, E.S.; Stevens, M. Progress towards the understanding and control of sugar beet rhizomania disease. Mol. Plant Pathol. 2009, 10, 129-141. [CrossRef] [PubMed] 
57. Norén, O.; Sjöström, H. Structure, biosynthesis and regulation of lactase-phlorizin hydrolase. Food Nutr. Res. 2001, 45, 156-160. [CrossRef]

58. Richards, S.; Gibbs, R.A.; Gerardo, N.M.; Moran, N.; Nakabachi, A.; Stern, D.; Tagu, D.; Wilson, A.C.C.; Muzny, D.; Kovar, C.; et al. Genome Sequence of the pea aphid Acyrthosiphon pisum. PLoS Biol. 2010, $8, \mathrm{e} 1000313$.

59. Nayak, A.; Berry, B.; Tassetto, M.; Kunitomi, M.; Acevedo, A.; Deng, C.; Krutchinsky, A.; Gross, J.; Antoniewski, C.; Andino, R. Cricket paralysis virus antagonizes Argonaute 2 to modulate antiviral defense in Drosophila. Nat. Struct. Mol. Biol. 2010, 17, 547-554. [CrossRef] [PubMed]

60. Van Rij, R.P.; Saleh, M.C.; Berry, B.; Foo, C.; Houk, A.; Antoniewski, C.; Andino, R. The RNA silencing endonuclease Argonaute 2 mediates specific antiviral immunity in Drosophila melanogaster. Genes Dev. 2006, 20, 2985-2995. [CrossRef] [PubMed]

61. Gordon, K.H.; Hanzlik, T.N. Tetraviruses. In The Insect Viruses; Springer: Berlin, Germany, 1998; pp. $269-299$.

62. Sparks, M.E.; Gundersen-Rindal, D.E.; Harrison, R.L. Complete genome sequence of a novel iflavirus from the transcriptome of Halyomorpha halys, the brown marmorated stink bug. Genome Announc. 2013, 1, e00910-13. [CrossRef] [PubMed]

63. Murakami, R.; Suetsugu, Y.; Kobayashi, T.; Nakashima, N. The genome sequence and transmission of an iflavirus from the brown planthopper, Nilaparvata lugens. Virus Res. 2013, 176, 179-187. [CrossRef] [PubMed]

64. Carrillo-Tripp, J.; Bonning, B.C.; Miller, W.A. Challenges associated with research on RNA viruses of insects. Curr. Opin. Insect Sci. 2015, 8, 62-68. [CrossRef]

65. Bonning, B.C. Editorial overview: Virus-insect interactions: Progress and pitfalls. Curr. Opin. Insect Sci. 2015, $8,7-9$.

(C) 2016 by the authors; licensee MDPI, Basel, Switzerland. This article is an open access article distributed under the terms and conditions of the Creative Commons Attribution (CC-BY) license (http://creativecommons.org/licenses/by/4.0/). 